\title{
A new unique recombinant HIV-1 revealed in Belarus
}

\author{
VF Eremin", EL Gasich, SV Sasinovich \\ From 17th International Symposium on HIV and Emerging Infectious Diseases (ISHEID) \\ Marseille, France. 23-25 May 2012
}

\section{Material and methods}

Blood plasma, EIA, western blot, RT-PCR, sequencing, SeqScape, BioEdit, Mega4.1, statistica 6.0, software.

\section{Results}

In April 2010 we have performed resistance tests of plasma sample obtained from patient Mos, 6 years old girl, born from HIV-infected mother. The phylogenetic analysis of the DNA fragment of patient Mos had shown that sample has been clustered with HIV-1 subtype A on gene pol, but was different from other analyzed samples, subtype A consensus IDU-A and reference sequences (AF004885). The Mos isolate is the most similar to AF413987 from Ukraine (subtype A) the p-distance was 0.066 . The comparison of sequences from gag gene $\mathrm{p} 17 /$ p24 region of Mos isolate with reference sequences HIV1 of subtype A demonstrates that average p-distance was 0.129 , and with reference sequences of subtype B was 0.075. Average $\mathrm{p}$-distance on gag gene (the Mos isolate) with CRF03_AB (AF414006.1, Belarus and AF193276.1 CRF03_AB KAL153) was 0.121 if compared with 0.013 $\mathrm{p}$-distance between reference sequences. The analysis of Mos isolate sequences on V3 loop gp120 gene env region HIV-1 has shown that average p-distance with reference isolates subtype B was 0.323 , and with A subtype was 0.155 . Average $\mathrm{p}$-distance sequence of Mos isolate with reference isolates AF414006.1 and AF193276.1 (CRF03_AB) was 0.308 .

\section{Conclusion}

Thus, it has been shown that Mos isolate is a unique recombinant form, but differs in genome structure from the one described earlier CRF03_ AB (AgagBpolBenv). The new recombinant HIV-1 has the following structure: BgagApolAenv. Sequences of new HIV-1 unique

\footnotetext{
* Correspondence: veremin@mail.ru
}

Briem, Minsk, Belarus

\section{Ciomed Central}

C 2012 Eremin et al; licensee BioMed Central Ltd. This is an Open Access article distributed under the terms of the Creative Commons Attribution License (http://creativecommons.org/licenses/by/2.0), which permits unrestricted use, distribution, and reproduction in any medium, provided the original work is properly cited. recombinant in gag, pol and env genes were submitted to EMBL/Genbank/DDBJ under accession numbers: FR775442.1, FN995656.1, FR775443.1.

Published: 25 May 2012

doi:10.1186/1742-4690-9-S1-P32

Cite this article as: Eremin et al: A new unique recombinant HIV-1 revealed in Belarus. Retrovirology 2012 9(Suppl 1):P32.

Submit your next manuscript to BioMed Central and take full advantage of:

- Convenient online submission

- Thorough peer review

- No space constraints or color figure charges

- Immediate publication on acceptance

- Inclusion in PubMed, CAS, Scopus and Google Scholar

- Research which is freely available for redistribution 